Jan Tichý: Электрическал эквивалентная схема затухаэщих колебаний изеиба...

проверка до сих пор выведенных формул. Одновременно будет полезно исследовать теоретически влияние внепнего трения на величины электрической әквивалентной схемы.

Толчок к работам, посвященным электрической эквивалентной схеме колебаний пьезоэлектрических плифов, дал проф. В. Петржилка. Я ему очень благодарен за постоянное внимание и за многие щенные советы. Выражаго искреннюю благодарность за некоторые замечания П. Халоупке и ассистенту Ф. Сошке.

Поступило 15. 10. 1955.

\title{
THE ELECTRICAL-EQUIVALENT CIRCUIT OF DAMPED FLEXURAL VIBRATIONS OF PIEZOELECTRIC BARS
}

\author{
(Abstract of preceding paper) \\ JAN TICHÝ \\ Chair of Mathematics and Physics, Faculty of Engineering, Liberec
}

The paper first gives the equation of motion for damped flexural vibrations of an infinitely thin bar (8) derived with regard to the damping caused by internal friction. If we consider the arrangement of electrodes shown in Fig. 3 for the piezoelectric excitation of flexural vibrations we can write the exciting moment of the piezoelectric strain in the form (11). $\xi(x)$ denotes the function of $x$ which, with the given arrangement of electrodes, takes on the values (12). The equation of motion for forced flexural vibrations of a piezoelectric bar (13) is solved by means of the series expansion (16). The vibrations in the stationary state have the same frequency as the exciting force but are displaced in phase. The mechanical deformations (30) are calculated and from them, by the usual method, the desired values of the electrical equivalent circuit $(40)-(43)$ are obtained. The effect of gaps between the electrodes and the piezoelectric bar is also considered.

Received. 15. 10. 1955.

\section{Jumepamypa - References}

[1] Cady W. G.: Piezoelectricity, Mc Graw-Hill, New York-London 1946.

[2] Chaloupka P.: Чехосл. физ. журн. 4 (1954), 453.

[3] Chaloupka P., Tichý J.: Slaboproudý obzor 16 (1955), 33. (In Czech).

[4] Keller J.: Wir. Eng. 28 (1951), 179.

[5] Mason W. P.: Piezoelectric Crystals and their Application to Ultrasonics, D. von Nostrand, New York 1950.

[6] Petržílka V.: Piezoelektřina, Př́rodovědecké vydavatelství, Praha 1951. (In Czech).

[7] Petrǔílka V., Kotler Al.: Věstník Královské české společnosti nauk, tř́ida matematicko-prírodovědecká (1947). (In Czech).

[8] Voigt W.: Lehrbuch der Kristallphysik, Teubner 1910.

[9] Wien W., Harms F.: Handbuch der Experimentalphysik, Akademische Verlagsgesellschaft, Leipzig 1910, sv. 17, dúl 1, str. 310. 